\author{
생활폐기물 자원화시설의 편익분석 \\ -강원도 중심으로- \\ 한영한 ${ }^{1}$, 이해승 ${ }^{*}$ \\ ${ }^{1}$ 강원발전연구원, ${ }^{2}$ 강원도립대학 소방환경방재과
}

\title{
Cost-Benefit Analysis by Resource Recovery Facility for Municipal Waste -Focus on Gangwon Province-
}

\author{
Young-Han $\operatorname{Han}^{1}$ and Hae-Seung Lee ${ }^{2^{*}}$ \\ ${ }^{1}$ Research Division I, Research Institute for Gangwon \\ ${ }^{2}$ Department of Fire Environmental \& Gangwon Provincial College
}

\begin{abstract}
요 약 본 연구에서는 자원화 가능한 폐기물의 양이 분석되었으며, 폐기물 자원화시설을 단독 또는 광역시설로 추 진할 경우의 설치비 및 운영비를 산정하고, 매립비용과 비교, 분석함으로서 자원화시설의 타당성을 검토하고자 하였 다. 자원화시설로는 고형연료화(RDF) 시설과 자원회수시설(소각)에 대한 검토를 수행하였다. 그리고, 강원도 각 시 군별 생활폐기물의 발생량과 가연성 폐기물의 비율을 고려하여 비용분석을 위한 광역권역을 설정하였다.

분석 결과, 단독시설의 경우에는 $\mathrm{RDF}$ 및 자원회수시설(소각) 모두 매립방식에 비교하여 경제적 편익이 없는 것으로 나타났다. 광역 시설의 경우, $\mathrm{RDF}$ 방식은 매립방식에 비해 많은 비용을 절감하는 것으로 나타났지만, 자소각 방식은 그렇지 않은 것으로 나타났다. 경제적 편익과는 별개로 화석 연료의 고갈, 지구온난화, 환경적 위해성, 그리고 사회적 갈등 등을 고려할 때 폐기물의 자원화는 중요하게 고려되어야 한다. 특히, 향후 CDM 사업이 활성화될 경우 CERs(온 실가스 저감인증)에 의한 추가적인 경제적 부가가치도 기대할 수 있을 것으로 나타났다. RDF 시설에 의한 $\mathrm{CERs}$ 는 약 2,565억원, 자원회수시설에 의한 CERs는 약 540 억원(단독시설) 및 774 억원(광역시설)으로 분석되었다.
\end{abstract}

\begin{abstract}
In this study, the amount of waste resource that could be recovered was analyzed. The installation and operation costs of waste resource recovery for both single- and multi-regional facility were calculated, and compared with the costs of landfill to investigate the feasibility of them. RDF(Refuse Derived Fuel) process and resource recovery by incineration process were considered as waste resource recovery facility. And, the multi-regions for cost analysis were established on the basis of the proper generation rate of municipal waste with the consideration of combustible ratio.

The study results showed that single region facility for both RDF and incineration process has no economic benefit, compared with the landfill method. For the multi-regional facility, RDF process could save a large cost than the landfill method, but the incineration facility couldn't. Separate from the economic benefits, the waste resource recovery should be importantly considered when considering the depletion of fossil fuel, global warming, environmental toxicity, and the enormous expenses due to social conflict and confuse. When the $\operatorname{CDM}($ Clean Development Mechanism) is vitalized in the near future, the additional economic benefits by CERs(Certified Emission Reductions) could be expected. CERs for RDF facility is corresponding to about 256.5 billion won, and CERs for incineration facility is corresponding to about 54 and 77.4 billion won for singleand multi-regional facility, respectively.
\end{abstract}

Key Words : Municipal Solid Wastes, Waste Resource Recovery Facility, NIMBY Phenomenon

\footnotetext{
"Corresponding Author : Hae-Seung Lee

Tel: +82-33-660-8182 email: haeseun@gw.ac.kr

접수일 12년 03월 30일수성일 (1차 12년

06월 01일, 2차 12년 06월 05일)

게재확정일 12 년 06월 07일
} 


\section{1. 서론}

유럽, 미국, 일본 등을 비롯한 선진국에서는 지속가능 국가발전의 원동력을 “에너지 안보”로 규정하고 “지속가 능한 경쟁력 있는 에너지 확보”를 목표로 기후변화협약 과 연계한 재생에너지정책을 추진하고 있다. 환경 (Environment), 경제(Economy), 에너지(Energy)를 함께 고려하는 $3 \mathrm{E}$ Goal 시대가 도래 하면서 신재생에너지에 대한 관심이 고조되고 있으며, 지구온난화와 자원고갈문 제에 대한 주요 대안 중 하나로서 자원순환형 폐기물관 리의 중요성도 더욱 높아지고 있다[1].

정부가 주요 정책기조로 추진 중인 녹색성장의 근저에 는 친환경이 자리하고 있으며, 친환경 녹색기술의 주요 부분 중 하나가 폐기물의 에너지 및 자원화이며, 2008년 환경부 기후변화대응종합계획에서도 “폐기물 에너지 자 원화”를 10 대 중점과제의 하나로 선정하고 있다[2]. 현재 신재생에너지 중 2007년 폐기물에너지의 비율은 $77 \%$ 에 달하며, 생산단가는 태양광의 $10 \%$, 풍력의 $66 \%$ 수준으 로 폐기물의 에너지화는 가장 효율적인 신재생에너지의 확대방안이 될 뿐만 아니라 녹색성장을 위한 주요 동력 이 되고 있다. 따라서 자원순환형 폐기물 관리체계의 구 축 및 정착은 고유가 시대 도래와 폐기물 관리 패러다임 의 변화, 온실가스 감축의무 가시화 등의 환경 변화 속에 서 향후 지속적으로 추진되어야 할 중요과제이다.

강원도는 단위면적당 온실가스 배출 부문에 있어서는 전국 최저 수준을 유지하고 있으나, 폐기물의 소각율과 재활용율은 전국 평균대비 낮은 수준이며 1 인당 폐기물 발생량은 전국 최고 수준에 이르고 있어, 발생저감 및 폐 기물자원의 효율화 방안의 강구가 시급한 실정이다. 강원 도의 매립시설은 2008 년말 기준 총 24개소로서 연간 유 지관리비는 약 105 억원으로서 향후 약 9 년간의 사용연한 여유가 있는 것으로 평가되며, 소각시설은 13 개소로 연 간 유지관리비는 약 83 억원에 달한다[3]. 현재 강원도는 자원순환형 사회 구축을 위한 폐기물의 자원화체계 구축, 경제적·환경적 효율성 제고, 사회적 갈등의 최소화를 위 해서는 광역 폐기물 관리체제로의 전환을 심각하게 고민 해야 할 시점이며, 자원화 및 광역화에 따른 지역주민의 환경적 안정성, 재정적 이익, 지역간 갈등 요소를 해소시 킬 수 있는 합리적 실행 방안이 모색되어야 한다. 그리고 폐기물 자원화 시설의 설치 및 유지에 필요한 국고지원, 융자 등 재정지원 등과 더불어 조세 감면 혜택 등의 인센 티브 제공을 통해 폐기물 자원화를 유인하기 위한 적극 적인 정책 및 제도의 개선이 요구된다.

본 연구에서는 강원도의 녹색성장에 있어 필수적인 부 분인 자원순환형(Zero-Waste) 사회 구축을 지향하는 중
요 요소인 공공 인프라의 체계적 구축에 있어, 생활폐기 물을 위주로 강원도내 폐기물 자원화 시설의 광역화 방 안에 대한 연구를 수행하였다.

\section{2. 조사방법}

\section{1 연구내용}

본 연구에서는 폐기물을 광역화하여 관리할 경우의 편 익을 검토하고자, 분석 내용을 단순화시켜 현재의 성상을 지닌 폐기물이 배출되는 조건을 기준으로, 자원화 가능한 대상폐기물을 단순 매립할 경우, 각 시군별로 독립 자원 화시설을 운영할 경우, 광역화된 자원화시설을 운영할 경 우에 대한 비교·분석을 수행하고자 한다.

이를 위하여, 시군별 자원화 가능한 폐기물량을 산정 하였으며, 매립방식에 의한 소요비용을 분석하였고, 매립 에 의한 비용 분석은 강원도의 실제 운영 실태를 분석하 여 가능한 현실적으로 반영되도록 하였다. 시군별로 독 립적인 자원화시설을 운영하는 경우, 쓰레기 고형연료화 (RDF) 시설과 자원회수시설(소각로)에 대한 비용 분석을 수행하였으며, 생활폐기물 발생량을 고려하여 광역화하 였을 경우에 대해서도 동일한 분석이 수행되었다. 이러한 각각의 방식에 대해 20 년간 운영하였을 경우에 대한 시 설비 및 유지관리비 등을 비교·분석하여 편익을 검토하고 자 하였다.

\section{2 연구방법}

생활폐기물 발생 및 처리현황 분석은 지역별 발생 및 처리실태, 폐기물의 성상, 폐기물 관리상의 문제점, 기존 매립/소각시설의 제반 현황 및 에너지화 추진 현황 등과, 폐기물 자원화/에너지화 추진 현황 및 주요 정책적 기반 및 강원도의 주요 추진전략 및 실태 등을 조사하고 추진 상의 문제점을 분석하였다. 강원도의 광역 체계 구축 방 안 분석은 도내 시·군의 폐기물 발생량, 처리권역 연계시 접근성 등을 고려하여 광역 처리권역의 시나리오를 설정 하고, 설정된 시나리오별로 환경적 - 경제적 기대효과 및 효율성 분석을 통해 매립방식 대비 편익을 분석하였다. 강원도의 효율적 시행방안 분석은 지역적 특성 및 폐기 물 배출실태를 고려한 정책 시행방안을 분석하였고, 강원 도의 현황을 고려한 광역 자원화시설의 효율성 제고 방 안에 대하여 제시하였다. 


\section{1 자원화 대상폐기물의 발생량을 고려한 광 역 처리권역 설정}

자원화시설의 설치에 있어 시·군별 단독시설로 설치할 경우와 광역처리시설로 설치하였을 경우의 경제성 및 효 율성을 비교 분석하기 위해 광역처리를 위한 권역(안)을 구분하고자 하였다. 이를 위해 우선 '08년 기준의 시군별 자원화 대상폐기물 발생량의 공간적 분포를 Fig. 1과 같 이 고찰하였으며, 그 결과 폐기물의 배출량이 많은 지역 은 원주, 춘천, 강릉, 평창, 속초 순 이였으며, 평창의 경 우에는, 재활용되는 나무류 폐기물의 양이 합산되어 높은 발생량을 나타내고 있다[4].

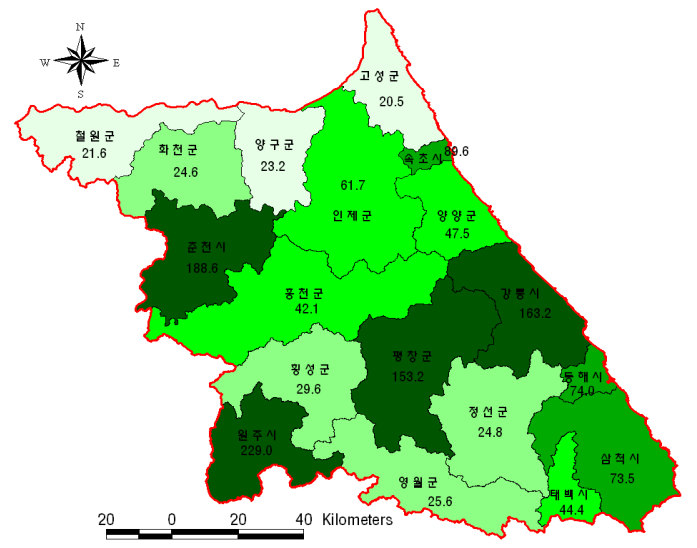

[그림 1] 시·군별 자원화 대상폐기물의 배출 현황 (톤/일)

[Fig. 1] Municipal waste discharge for each city and county (ton/day)

상기발생량 분포 현황을 기본으로, 강원도 18 개 시군 을 자원화 가능폐기물의 발생량, 접근용이성 등을 고려한 효율적 폐기물처리를 위해 Fig. 2와 같이 5개 권역으로 구분하였다. $\mathrm{A}$ 권역은 춘천, 철원, 화천, 양구, $\mathrm{B}$ 권역은 속초, 인제, 고성, 양양, $\mathrm{C}$ 권역은 원주, 횡성, 홍천, $\mathrm{D}$ 권 역은 평창, 태백, 영월, 정선, $\mathrm{E}$ 권역은 강릉, 동해, 삼척 으로 구분하였다. 경제적 효율성을 고려할 때, 권역 내에 서 가장 많은 폐기물이 발생하는 지역에 처리시설이 입 지하는 것이 효율적이므로 각 권역에서 가장 높은 폐기 물 발생량을 보이는 춘천, 속초, 원주, 평창, 강릉을 광역 처리시설의 입지지역으로 가정하고 분석을 수행하였다. 이들 도시 중 평창을 제외하고는 이미 폐기물 에너지화 시설이 가동 중이거나 시설 설치를 계획하고 있는 지역 인 것으로 조사되었다[3].

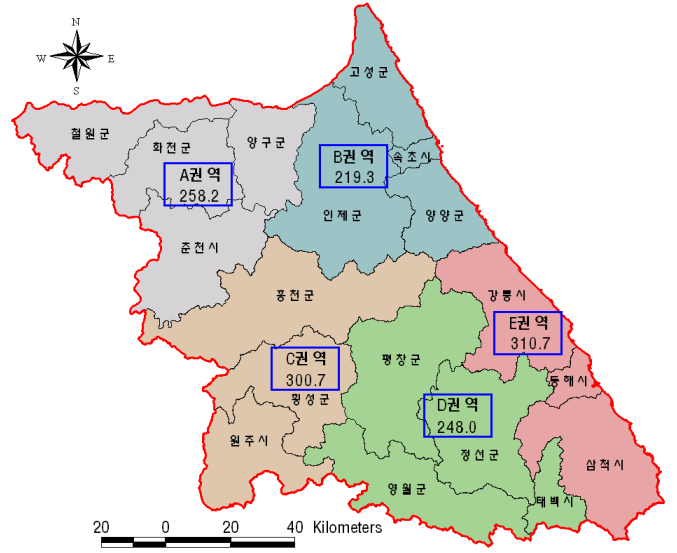

[그림 2] 폐기물 자원화를 위한 광역권 설정(안)

[Fig. 2] Establishment of multi-regional area for waste resources recovery

\section{2 자원화 대상 폐기물량 및 매립비용 분석}

\subsection{1 폐기물 매립에 대한 기준 비용 산정}

매립 방식에 의한 폐기물처리 비용은 매립시설 설치비 용과 유지관리비용으로 구분된다. 이러한 비용을 산정하 기 위해서는 입지지역에 따른 토지수용비용, 시설규모, 처리량, 물가상승율, 이자율 등도 함께 고려되어야 하나, 이는 설치시기 및 입지지역에 따라 다양한 요소가 영향 을 미치고 있으며, 시군별 설치비용 및 관리비용에서도 그 차이가 확연히 드러난다. 본 연구에서는 각 시군의 자 원화가능 처리 대상량에 대하여 기준척도를 두어 상대적 인 비교분석을 수행하고자 하였다. 강원도 내에 설치 및 운영되고 있는 매립지에 대한 설치비용 및 유지관리비용 을 분석하기 위해 2008년을 기준으로 매립지를 설치하고 향후 20 년간 운영한다는 시나리오를 설정하여 비용 분석 을 수행하였다. 물가 상승율 및 이자율 등은 고려하지 않 고 상대적인 비교·분석을 수행하였다.

\section{1) 매립지 설치의 기준비용 분석}

2008년 기준으로 강원도에서 운영되고 있는 매립지 24 개소에 대하여 각 지자체의 자료를 수집하여 매립지 용량과 설치비에 대한 회귀분석의 수행 결과를 Fig. 3 에 제시하였다. 분석된 매립지 24개소의 설치년도는 '95 '07 년 사이의 12 년 간격을 두고 설치된 것으로 나타나, 물가 상승률 등을 고려할 때 매립지 설치의 기준비용으로 하 기에는 무리가 있는 것으로 나타났다. 특히, '95년에 설 치된 원주 매립장의 경우(가장 왼쪽의 점), 용량이 가장 크면서도 설치비는 상당히 낮게 나타나는 현상을 나타내 고 있다. 설치시기의 연차가 너무 상이해 매립용량에 따 
른 기준비용을 산정하기에는 현실성이 결여된다고 판단 되어, 2000년 이전에 설치된 매립지는 제외하고 2000 2007년 사이에 운영이 개시된 매립지를 대상으로 하여 기준 설치비용 산정식을 구하기 위한 Fig. 4와 같이 회귀분석을 수행하였다.

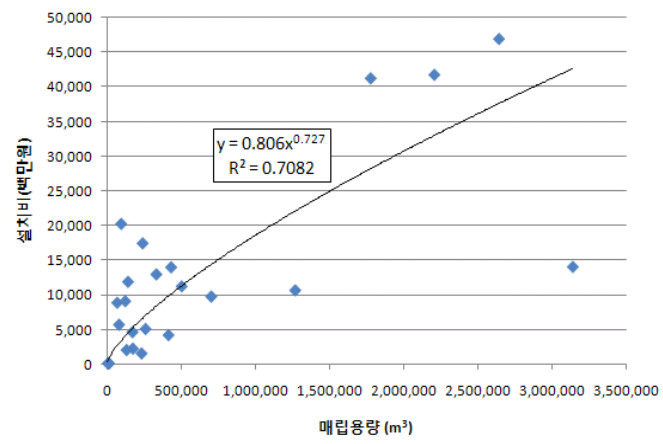

[그림 3] 매립지 용량-설치비의 상관관계(24개소)

[Fig. 3] Relationship between capacity and installation cost of landfill sites (24 sites)

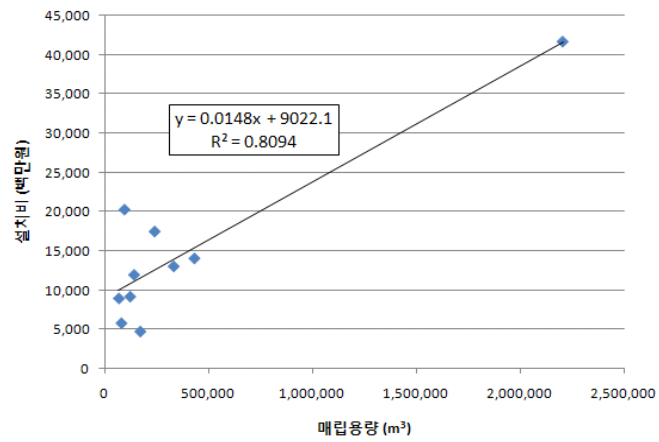

[그림 4] 매립지 용량-설치비 상관관계(10개소)

[Fig. 4] Relationship between capacity and installation cost of landfill sites (10 sites)

\section{2) 매립량에 따른 유지관리 비용 산정}

폐기물관리법에 따라 2009년 환경부에서 고시된 '방 치폐기물처리 이행보증금 산출을 위한 폐기물 종류별 처 리단가'에서는 매립에 의한 처리비용이 67천원/톤으로 명시되어 있으며, 소각은 266천원/톤으로 명시되어 있다 [5]. 그러나 이는 지역의 특성을 고려하기 어려운 전국적 인 평균 수치이며, 강원도는 면적에 비해 인구밀집도가 낮다는 특성이 있으므로 본 연구에서는 강원도 각 지자 체 매립지의 2008년도 유지관리 비용 지출내역을 사용하 여 매립량에 대한 유리관리비용의 산정식을 구하고자 하 였다. 매립량에 유지관리 비용의 기준단가를 산정하기 위 하여 현재 운영되고 있는 매립지 24개소에 대하여, 매립 량 유지관리비에 대한 회귀분석을 수행하였다. 매립량 및 유지관리비용은 각 시군의 2008년 자료를 이용하여 그 결과를 Fig. 5에 제시하였다. 매립량과 유지관리비용과의 상관관계는 선형식에서 가장 높은 상관계수 $\left(\mathrm{R}^{2}\right)$ 를 나타 내었으며, 지역에 따라 비교적 큰 편차 없이 높은 상관성 을 나타내는 것으로 분석되었다.

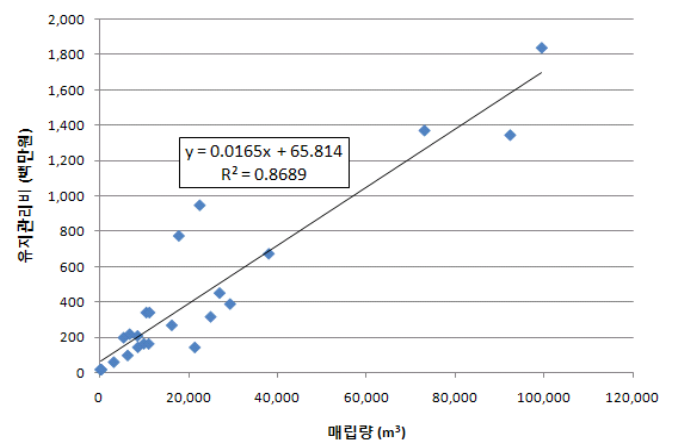

[그림 5] 매립량과 유지관리비의 상관관계

[Fig. 5] Relationship between the amount of landfill and operation cost

[표 1] 시·군별 수집·운반처리비용 기준 단가

[Table 1] Unit cost of municipal waste collection and transportation for each city and county

\begin{tabular}{c|c|c|c|c|c|c|c}
\hline 시·군 & $\begin{array}{c}\text { 수집 } \\
\text { 운반량(톤/일) }\end{array}$ & $\begin{array}{c}\text { 연간 수집 } \\
\text { 운반비(천원) }\end{array}$ & $\begin{array}{c}\text { 기준 단가 } \\
\text { (원/톤) }\end{array}$ & $\begin{array}{c}\text { 수집 } \\
\text { 운반량(톤/일) }\end{array}$ & $\begin{array}{c}\text { 연간 수집 } \\
\text { 운반비(천원) }\end{array}$ & $\begin{array}{c}\text { 기준 단가 } \\
\text { (원/톤) }\end{array}$ & $\begin{array}{c}\text { 기준 단가 } \\
\text { (원/톤) }\end{array}$ \\
\hline \hline 춘천시 & 345.0 & $7,943,059$ & $63,077.7$ & 영월군 & 38.7 & $3,670,832$ & $259,872.7$ \\
\hline 원주시 & 386.4 & $14,759,222$ & $104,648.6$ & 평창군 & 180.0 & $3,182,282$ & $48,436.6$ \\
\hline 강릉시 & 307.3 & $18,043,582$ & $160,867.1$ & 정선군 & 48.2 & $3,750,474$ & $213,179.9$ \\
\hline 동해시 & 113.8 & $8,132,783$ & $195,796.1$ & 철원군 & 42.4 & $3,255,801$ & $210,377.4$ \\
\hline 태백시 & 120.7 & $4,445,508$ & $100,907.0$ & 화천군 & 48.6 & $1,064,920$ & $60,032.7$ \\
\hline 속초시 & 197.3 & $1,913,685$ & $26,573.6$ & 양구군 & 35.2 & $1,245,010$ & $96,903.0$ \\
\hline 삼척시 & 101.0 & $5,096,476$ & $138,247.0$ & 인제군 & 83.7 & $2,248,460$ & $73,598.1$ \\
\hline 홍천군 & 73.3 & $2,749,572$ & $102,738.2$ & 고성군 & 31.4 & $3,100,865$ & $270,870.9$ \\
\hline 횡성군 & 57.2 & $2,642,000$ & $126,544.7$ & 양양군 & 71.1 & $2,290,447$ & $88,258.8$ \\
\hline
\end{tabular}




\section{3) 시·군별 수집운반비 분석}

생활폐기물 연간 수집운반비용은 종량제 봉투 배출폐 기물 이외에도 재활용가능 분리배출폐기물, 음식물류 등 의 비용이 합산된다. 따라서 수집운반량은 생활자원화대 상 폐기물량이 포함된 생활폐기물의 총량을 고려하여 시. 군별 수집운반비의 기준단가를 산정하였다.

산정된 수집운반비의 기준 단가는 약 27 천원/톤 270 천원/톤으로 약 10 배의 폭 넓은 범위를 나타내었다.

속초, 평창, 화천, 춘천, 인제, 양구 등에서는 약 100 천 원/톤 이하의 비교적 낮은 기준단가를 나타내었는데, 이 는 지역 면적과 인구밀도의 지역적 특성, 나무류 폐기물 의 발생, 그리고 군부대가 다수 위치하여 배출폐기물이 매립지로 직접 이송되는 등의 영향인 것으로 판단된다. 고성, 영월, 정선, 철원 등의 시군은 200 천원/톤 이상의 높은 수거운반비 기준 단가를 보이고 있다. 속초시 및 평 창군은 50 천원/톤의 가장 낮은 수거운반비를 나타내었는 데 이는 비교적 작은 수거면적 및 나무류 등의 폐기물 발 생에 기인한 것으로 판단된다. 강원도 전체의 수집운반비 평균 단가는 약 108 천원/톤인 것으로 나타났다.

\subsection{2 매립 방식에 의한 폐기물 처리비용 산정}

폐기물관리법에 관련된 2008년 환경부고시에 따르면
'방치폐기물처리 이행보증금 산출을 위한 폐기물 종류별 처리단가'에서는 매립시설의 설치단가는 시 지역 20 천원/ $\mathrm{m}^{3}$, 군 지역은 40 천원 $/ \mathrm{m}^{3}$ 이며, 유지관리비용은 67 천원/톤 으로서 단위체적당 폐기물량 $\left(0.4\right.$ 톤 $\left./ \mathrm{m}^{3}\right)$ 을 고려하면[5], 매 립에 의한 처리단가는 시 지역의 경우 117 천원/톤, 군 지 역의 경우 166 천원/톤으로서 평균 136 천원/톤인 것으로 나타났다. 본 연구에서는 강원도의 실질적인 설치비 및 유지관리비를 최대한 반영하기 위하여 이 기준단가를 사 용하지 않고, 2008년 기준으로 강원도에서 운영중인 매 립지 24개소에 대해 분석된 유지관리비의 상관식과, 2000 년 이후에 설치된 매립지 10 개소에 대해 분석된 시 설설치비의 상관식을 활용하여 설치비와 유지관리비용 등 매립에 의한 총 처리비용은 산정하여 매립시 톤당 처 리비용(기준단가)을 산정하였다. $\mathrm{RDF}$ 및 자원회수시설 등과의 처리비용 및 편익을 비교·평가하기 위하여 매립 기준용량은 20 년으로 설정하였으며, ' 08 년 현재 매립 또 는 소각되는 자원화 대상폐기물이 모두 매립되는 경우에 대한 매립비용을 추정하였다. 매립용량은 여유율 $10 \%$ 를 두어 최종 용량을 산정하였다. 매립지의 설치비 중 국비 지원율은 24 개 매립지의 평균 비율은 $30 \%$ 를 이용하여 총 처리비용 중 지방비 소요액을 산정하였다. 매립비용 산정에서 사용된 주요 기준은 단위체적당 폐기물량 : 0.4

[표 2] 자원화 대상폐기물에 대한 총 매립비용 산정결과(20년간)

[Table 2] Total landfill cost of municipal waste discharged for 20 years

\begin{tabular}{|c|c|c|c|c|c|c|c|c|}
\hline 구분 & $\begin{array}{c}\text { 자원화 대상량 } \\
\text { (톤/일) }\end{array}$ & $\begin{array}{c}\text { 20년 기준 } \\
\text { 매립용량 }\left(m^{3}\right)\end{array}$ & $\begin{array}{c}\text { 설치비 } \\
\text { (백만원) }\end{array}$ & \begin{tabular}{|c|} 
유지 \\
관리비(백만원)
\end{tabular} & $\begin{array}{l}\text { 총 비용 } \\
\text { (백만원) }\end{array}$ & \begin{tabular}{|c|} 
연간 \\
처리비(백만원)
\end{tabular} & $\begin{array}{c}\text { 톤당 } \\
\text { 처리비(원) }\end{array}$ & \begin{tabular}{|c} 
지방비 \\
소요액(백만원)
\end{tabular} \\
\hline 계 & $1,336.7$ & $33,541,905$ & 658,818 & 504,313 & $1,163,131$ & 58,157 & 86,692 & 965,486 \\
\hline 춘천시 & 18188.6 & $4,732,681$ & $\begin{array}{l}79,066 \\
\end{array}$ & 71,056 & 150,122 & $7,7,506$ & $\begin{array}{l}79,301 \\
\end{array}$ & 126,402 \\
\hline 원주시 & 229.0 & $5,746,469$ & 94,070 & 86,263 & 180,333 & 9,017 & 78,454 & 152,112 \\
\hline 강릉시 & 163.2 & $4,095,300$ & 69,633 & 61,495 & 131,128 & 6,556 & 80,048 & 110,238 \\
\hline 동해시 & 74.0 & $1,856,938$ & 36,505 & 27,920 & 64,425 & 3,221 & 86,735 & 53,473 \\
\hline 태백시 & 44.4 & $1,114,163$ & 25,512 & 16,778 & 42,290 & 2,114 & 94,892 & 34,636 \\
\hline 속초시 & 89.6 & $2,248,400$ & 42,298 & 33,792 & 76,090 & 3,805 & 84,605 & 63,401 \\
\hline 삼척시 & 73.5 & $1,844,391$ & 36,319 & 27,732 & 64,051 & 3,203 & 86,818 & 53,155 \\
\hline 홍천군 & 42.1 & $1,056,447$ & 24,658 & 15,913 & 40,570 & 2,029 & 96,006 & 33,173 \\
\hline 횡성군 & 29.6 & 742,775 & 20,015 & 11,207 & 31,223 & 1,561 & 105,088 & 25,218 \\
\hline 영월군 & 25.6 & 642,400 & 18,530 & 9,702 & 28,231 & 1,412 & 109,867 & 22,673 \\
\hline 평창군 & 153.2 & $3,844,363$ & 65,919 & 57,731 & 123,650 & 6,182 & 80,410 & 103,874 \\
\hline 정선군 & 24.8 & 622,325 & 18,233 & 9,401 & 27,633 & 1,382 & 111,008 & 22,163 \\
\hline 철원군 & 21.6 & 542,025 & 17,044 & 8,196 & 25,240 & 1,262 & 116,416 & 20,127 \\
\hline 화천군 & 24.6 & 617,306 & 18,158 & 9,325 & 27,484 & 1,374 & 111,305 & 22,036 \\
\hline 양구군 & 23.2 & 582,175 & 17,638 & 8,798 & 26,437 & 1,322 & 113,526 & 21,145 \\
\hline 인제군 & 61.7 & $1,548,284$ & 31,937 & 23,290 & 55,227 & 2,761 & 89,174 & 45,646 \\
\hline 고성군 & 20.5 & 513,512 & 16,622 & 7,768 & 24,391 & 1,220 & 118,744 & 19,404 \\
\hline 양양군 & 47.5 & $1,191,953$ & 26,663 & 17,945 & 44,608 & 2,230 & 93,561 & 36,609 \\
\hline
\end{tabular}

* 향후 20 년간의 지방비 소요액은단위체적당 폐기물량 $\left(0.4\right.$ 톤 $\left./ \mathrm{m}^{3}\right)$, 복토용량(매립용량의 $\left.25 \%\right)$, 설치비에 대한 국고 지원율(30\%), 매립지 설 치용량 여유율 $(10 \%)$ 의 기준으로 산정됨 
톤 $/ \mathrm{m}^{3}$, 복토용량 : 매립용량의 $25 \%$, 설치비에 대한 국고 지원율 : $30 \%$, 매립지 설치용량 여유율 : $10 \%$ 로 적용하 였다.

매립에 의한 톤당 처리비용은 $80,048 ~ 118,744$ 원/톤으 로 상기의 117 천원/톤 166 천원/톤 보다는 낮게 산정되었 다. 원주, 춘천, 강릉 등의 시 지역에서 기준단가가 낮게 나타났으며, 정선, 철원, 화천, 양구, 고성 등에서 높은 단 가를 나타내었다. 산정된 자원화 대상폐기물량을 모두 매 립할 경우, 지원되는 국비를 제외하고 강원도 및 각 시군 이 20 년간 소요해야 될 지방비는 약 9,655 억원인 것으로 추정되었으며, 평창군은 재활용되는 나무류가 매립량에 함께 포함되어 약 1,039 억원의 높은 비용이 산정되었다.

\section{3 고형연료화(RDF) 시설에 의한 처리 비용 및 편익 분석}

\subsection{1 경제적 편익 분석}

국내의 경우, $\mathrm{RDF}$ 관련시설은 여전히 설치 초기단계 에 있어, 적용기술, 지역여건 등의 외부요인 편차가 커 투 입 폐기물량 기준의 톤당 시설비용 단가가 일정하지 않 게 나타나는 경향이 있다. 따라서 투입 폐기물량에 따른 $\mathrm{RDF}$ 시설 설치비를 산정하기 위하여, $\mathrm{RDF}$ 처리시설을 운영중인 “원주시 생활폐기물 에너지화시설 설치 운영 (원주시, 2010)" 자료를 참고로 하여 현실적인 시설 투자 비용에 대한 자문을 통해 다음과 같이 시설용량과 설치 비의 관계로부터 산정식을 구하였다. $\mathrm{RDF}$ 제조시설의 경우, 폐기물 투입물 톤당 운영비의 단가는 시설 규모가 클수록 운영비 단가가 감소하는 추세를 보이는 것으로 나타났으며, Fig. 6과 7에서 산정된 관계식으로부터 시설 의 규모별 운영비 단가를 산정하고자 하였다[6].

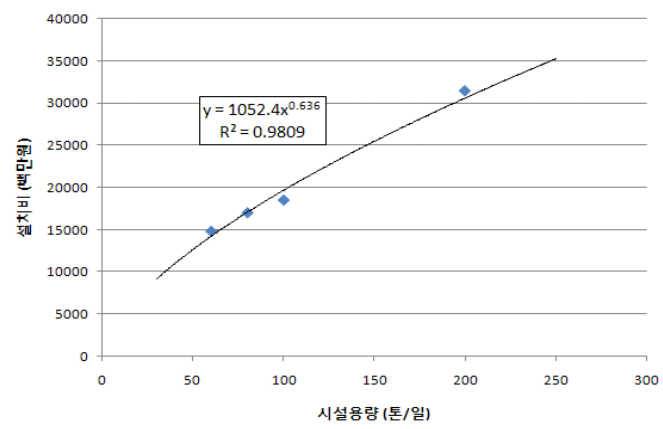

[그림 6] RDF 시설용량과 설치비의 상관관계

[Fig. 6] Relationship between capacity and installation cost of RDF facility

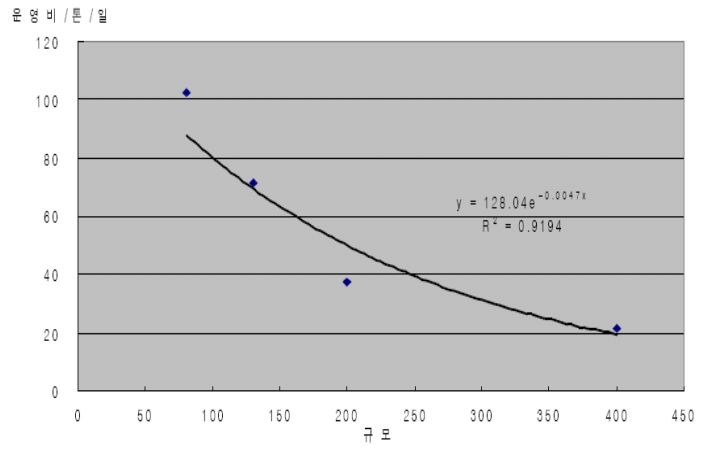

[그림 7] RDF 제조시설 규모별 운영비 단가

[Fig. 7] Relationship between capacity and the unit operation cost of RDF facility

시·군별 단독설치의 경우, 상기의 시설 산정기준을 이 용하여 설치비 및 운영비를 산정하였다. 운영비는 매립에 의한 폐기물 처리비용과 비교·분석하기 위하여 20 년간의 운영비를 산정하였다. 시설용량은 1 일 2 교대 방식(원주 시)의 운영시간 16 시간을 기준으로 산정하였다. 생산되 는 $\mathrm{RDF}$ 의 양은 원주시 $\mathrm{RDF}$ 시설자료를 참조하여 가연 성의 $60 \%$ 로 설정하였으며, $\mathrm{RDF}$ 판매액은 원주에서 $\mathrm{RDF}$ 를 판매하는 금액인 25,000 원/톤으로 산정하였다. 생산된 $\mathrm{RDF}$ 를 수요처로 이동시키는데 소요되는 운송비는 19,899 원/톤(50km, 25톤 트럭 기준)으로 설정하였다[7].

음식물류 등 가연성폐기물의 $15 \%$ 는 선별되어 매립되 는 것으로 가정하였으며, 각 시군의 불연성폐기물의 비 율에 따라 매립량 및 그에 따른 매립비용을 산정하여 총 처리비용을 산정하였다. 그리고 $\mathrm{RDF}$ 판매액, 수송비를 모두 고려하여 최종 소요비용과 톤당 처리비용을 산정하 고, 국비 지원기준(톤당 시설비 1.5 억, 국비 $30 \%$ 지원)을 고려하여 지방비 소요액을 산정하였다. RDF 시설은, 시 설용량이 큰 춘천시, 원주시, 강릉시, 평창군의 경우에는 매립비용에 비해 경제적인 측면에서도 긍정적이나, 용량 이 작은 나머지 지자체는 매립비용에 비해 많은 처리비 용이 소요되는 것으로 나타났다. 강원도 각 시군이 모두 단독시설을 설치할 경우 매립비용보다 약 2,840 억원이 더 소요되는 것으로 분석되었다.

광역화의 경우 시·군별 $\mathrm{RDF}$ 시설 설치 시와 동일한 산 정기준을 이용하여, $\mathrm{A} \sim \mathrm{E}$ 권역의 5 개 권역으로 광역화할 경우에 대한 설치비 및 20 년간의 운영비를 산정하였다. 시설용량, 가연성 및 불연성폐기물의 산정방식, $\mathrm{RDF}$ 의 생산량 및 판매액 또한 동일한 기준을 활용하여 분석하 였다. 운송비의 경우, 수거된 자원화대상 생활폐기물은 광역 시설이 입지된 지역까지의 운송되는 비용과 권역별 운송거리 활용)과 생산된 $\mathrm{RDF}$ 를 수요처로 이동시키는데 
[표 3] 단독 및 광역 $\mathrm{RDF}$ 시설에 의한 생활폐기물 처리비용 산정

[Table 3] Cost analysis for municipal waste treatment by individual and multi regional RDF facility

\begin{tabular}{|c|c|c|c|c|c|c|c|}
\hline 구 분 & $\begin{array}{l}\text { 시설용량 } \\
\text { (톤/일) }\end{array}$ & $\begin{array}{c}\text { 처리비용 } \\
\text { (시설+운영+매립) } \\
\text { (백만원) }\end{array}$ & $\begin{array}{c}\mathrm{RDF} \\
\text { 판매액(백만원) }\end{array}$ & $\begin{array}{c}\mathrm{RDF} \\
\text { 수송비(백만원) }\end{array}$ & $\begin{array}{c}\text { 최종 } \\
\text { 소요비용(백만원) }\end{array}$ & $\begin{array}{c}\text { 톤당 처리비용 } \\
\text { (원/톤) }\end{array}$ & $\begin{array}{c}\text { 지방비 소요액 } \\
\text { (백만원) }\end{array}$ \\
\hline 계 & 2,005 & $1,363,150$ & 114,643 & 91,246 & $1,339,753$ & 91,535 & $1,249,529$ \\
\hline 춘천시 & 283 & 149,806 & 15,615 & 12,428 & 146,620 & 106,495 & 133,889 \\
\hline 원주시 & 344 & 154,966 & 20,761 & 16,524 & 150,729 & 90,165 & 135,271 \\
\hline 강릉시 & 245 & 131,308 & 15,363 & 12,228 & 128,173 & 107,585 & 117,157 \\
\hline 동해시 & 111 & 88,647 & 5,716 & 4,549 & 87,481 & 161,942 & 82,486 \\
\hline 태백시 & 67 & 58,563 & 3,920 & 3,120 & 57,763 & 178,216 & 54,766 \\
\hline 속초시 & 134 & 100,727 & 6,953 & 5,534 & 99,308 & 151,829 & 93,260 \\
\hline 삼척시 & 110 & 94,453 & 4,413 & 3,512 & 93,552 & 174,359 & 88,591 \\
\hline 홍천군 & 63 & 54,685 & 4,008 & 3,190 & 53,867 & 175,275 & 51,025 \\
\hline 횡성군 & 44 & 47,899 & 1,785 & 1,421 & 47,535 & 219,987 & 45,537 \\
\hline 영월군 & 38 & 43,050 & 1,511 & 1,203 & 42,742 & 228,713 & 41,014 \\
\hline 평창군 & 230 & 121,596 & 15,680 & 12,480 & 118,396 & 105,865 & 108,055 \\
\hline 정선군 & 37 & 37,034 & 2,256 & 1,795 & 36,574 & 202,020 & 34,900 \\
\hline 철원군 & 32 & 34,580 & 1,763 & 1,403 & 34,221 & 217,026 & 32,763 \\
\hline 화천군 & 37 & 40,209 & 1,697 & 1,351 & 39,862 & 221,975 & 38,202 \\
\hline 양구군 & 35 & 38,940 & 1,522 & 1,211 & 38,630 & 228,093 & 37,064 \\
\hline 인제군 & 93 & 75,610 & 5,234 & 4,166 & 74,542 & 165,498 & 70,377 \\
\hline 고성군 & 31 & 30,354 & 2,087 & 1,661 & 29,928 & 200,344 & 28,547 \\
\hline 양양군 & 71 & 60,720 & 4,358 & 3,469 & 59,831 & 172,547 & 56,624 \\
\hline 광역처리 & $\begin{array}{l}\text { 시설용량 } \\
\text { (톤/일) }\end{array}$ & $\begin{array}{c}\text { 처리비용 } \\
\text { (시설+운영+매립) } \\
\text { (백만원) }\end{array}$ & $\begin{array}{c}\mathrm{RDF} \\
\text { 판매액 } \\
\text { (백만원) }\end{array}$ & $\begin{array}{l}\text { 운송비 }^{*} \\
\text { (백만원) }\end{array}$ & $\begin{array}{c}\text { 최종 } \\
\text { 소요비용 } \\
\text { (백만원) }\end{array}$ & $\begin{array}{c}\text { 톤당 처리비용 } \\
\text { (원/톤) }\end{array}$ & $\begin{array}{c}\text { 지방비 소요액 } \\
\text { (백만원) }\end{array}$ \\
\hline 계 & 2,005 & 873,128 & 114,643 & 165,782 & 924,268 & 94,722 & 773,893 \\
\hline A권역 & 387 & 181,692 & 20,597 & 27,642 & 188,738 & 100,211 & 159,713 \\
\hline $\mathrm{B}$ 권역 & 329 & 164,688 & 18,633 & 28,336 & 174,391 & 108,952 & 149,724 \\
\hline $\mathrm{C}$ 권역 & 451 & 177,383 & 26,554 & 30,623 & 181,452 & 82,662 & 147,623 \\
\hline $\mathrm{D}$ 권역 & 372 & 160,987 & 23,367 & 35,532 & 172,952 & 95,532 & 145,052 \\
\hline $\mathrm{E}$ 권역 & 466 & 188,378 & 25,492 & 43,580 & 206,736 & 91,149 & 171,782 \\
\hline
\end{tabular}

"운송비는 광역시설로의 생활폐기물 운송비와 생산된 RDF의 운송비가 합산된 결과임

소요되는 운송비를 함께 고려하여 산정하였다. 광역화시 설의 경우 시설설치비에 대해 국비 $50 \%$ 가 지원되므로(톤 당 시설비 1.5 억) 이를 고려하여 지방비 소요액을 산정하 였다. 시설설치 및 운영에 소요되는 지방비는 향후 20 년 동안 약 7,739억원이 소요되는 것으로 나타났다. 이는 시. 군별로 단독시설을 설치하는 것에 비해 약 4,750 억원 이 상의 지방비가 절감되는 것이며, 매립방식에 비해서 약 1,916 억원의 비용이 절감되는 것으로 나타나 강원도 전 체에서 매년 약 95 억원의 경제적 편익이 있는 것으로 분 석되었다.

\subsection{2 환경적 편익 분석}

$\mathrm{RDF}$ 시설은 폐기물을 고형연료로 생성하여 에너지화 함으로서 원유사용을 대체하여 온실가스를 감축시키는 환경적 편익을 지닌다. 따라서, $\mathrm{RDF}$ 시설의 설치 및 운 영으로 인해 기대되는 매립지의 사용연한 증대, 원유대체 효과(T.O.E), 온실가스감축량, CERs 등에 대한 환경적 기
대효과를 2008년 환경부 “폐기물 에너지화 종합대책”에 서의 기준을 이용하여 평가하였다[9].

- 원유대체효과 : RDF 0.5 톤 $\times 1,000 \mathrm{~kg} /$ 톤 $\times$ $4,800 \mathrm{kcal} / \mathrm{kg}=2,400,000 \mathrm{kcal}=0.24 \mathrm{TOE}$

- 온실가스감축량 : $0.24 \mathrm{TOE} \times 3.883$ 톤 $/ \mathrm{TOE}=0.932$ 톤

- CERs : 0.932톤 $\times \varnothing 11 /$ 톤 $\times 1,363.94$ 원/ Ø $=13,982$ 원

$\mathrm{RDF}$ 시설을 설치하고 20 년간 운영할 경우 환경적 기 대효과를 분석한 결과, 매립지 사용연한은 현재 9년에 비 해 약 3.0 배 증가할 것으로 산정되어 강원도는 평균적으 로 약 27년간의 사용연한을 확보할 수 있을 것으로 분석 되었다. 또한, 향후 20 년간 약 440 만 TOE의 원유대체효 과를 기대할 수 있으며, 이에 따른 온실가스 감축량은 약 1,709 만톤에 달하는 것으로 분석되었다. 이는 약 2,565 억 원의 $\mathrm{CERs}$ 에 해당하는 것으로 향후 $\mathrm{CDM}$ (Clean Development Mechanism) 사업이 활성화될 경우 추가적 
[표 4] 폐기물 고형연료화를 통한 환경적 기대효과

[Table 4] Environmental effect by RDF production using municipal waste

\begin{tabular}{|c|c|c|c|c|c|}
\hline \multicolumn{2}{|c|}{ 구 분 } & $\begin{array}{c}\text { 매립지 사용연한 } \\
\text { 증대 효과 (배) }\end{array}$ & $\begin{array}{c}\text { 원유대체효과 } \\
\text { (T.O.E) }\end{array}$ & $\begin{array}{c}\text { 온실가스감축량 } \\
\text { (톤) }\end{array}$ & CERs (억원) \\
\hline \multicolumn{2}{|c|}{ 계 } & 3.0 & $4,402,273$ & $17,094,026$ & $2,564.7$ \\
\hline \multirow{8}{*}{ 시 } & 춘천시 & 2.8 & 599,604 & $2,328,264$ & 349.3 \\
\hline & 원주시 & 3.4 & 797,230 & $3,095,644$ & 464.5 \\
\hline & 강릉시 & 3.7 & 589,933 & $2,290,712$ & 343.7 \\
\hline & 동해시 & 2.5 & 219,491 & 852,282 & 127.9 \\
\hline & 태백시 & 3.2 & 150,532 & 584,515 & 87.7 \\
\hline & 속초시 & 2.5 & 267,005 & $1,036,780$ & 155.6 \\
\hline & 삼척시 & 1.9 & 169,453 & 657,988 & 98.7 \\
\hline & 홍천군 & 3.8 & 153,896 & 597,577 & 89.7 \\
\hline \multirow{3}{*}{ 군 } & 횡성군 & 1.9 & 68,538 & 266,134 & 39.9 \\
\hline & 영월군 & 1.8 & 58,026 & 225,316 & 33.8 \\
\hline & 평창군 & 4.9 & 602,127 & $2,338,061$ & 350.8 \\
\hline \multirow[t]{7}{*}{ 별 } & 정선군 & 3.4 & 86,619 & 336,341 & 50.5 \\
\hline & 철원군 & 2.7 & 67,697 & 262,869 & 39.4 \\
\hline & 화천군 & 2.2 & 65,174 & 253,072 & 38.0 \\
\hline & 양구군 & 2.0 & 58,447 & 226,949 & 34.0 \\
\hline & 인제군 & 2.9 & 200,989 & 780,442 & 117.1 \\
\hline & 고성군 & 4.8 & 80,159 & 311,258 & 46.7 \\
\hline & 양양군 & 3.5 & 167,351 & 649,824 & 97.5 \\
\hline \multirow{5}{*}{$\begin{array}{l}\text { 권 } \\
\text { 역 } \\
\text { 별 }\end{array}$} & A권역 & 2.6 & 790,923 & $3,071,154$ & 460.8 \\
\hline & B권역 & 2.9 & 715,504 & $2,778,304$ & 416.8 \\
\hline & C권역 & 3.2 & $1,019,664$ & $3,959,355$ & 594.0 \\
\hline & $\mathrm{D}$ 권역 & 3.7 & 897,304 & $3,484,233$ & 522.8 \\
\hline & E권역 & 2.8 & 978,877 & $3,800,981$ & 570.3 \\
\hline
\end{tabular}

인 경제적 부가가치도 기대할 수 있을 것으로 판단된다. 이러한 CERs에 의한 경제적 부가가치를 포함하면, 시·군 별 단독 RDF 시설을 설치할 경우에도 매립에 의한 방법 보다 향후 20 년간 약 276 억원의 비용이 더 소요되는 것 으로 나타났으며, 광역화 시설의 경우에는 약 4,480 억원 의 편익을 기대할 수 있을 것으로 분석되었다.

\section{4 자원회수시설(소각)의 편익 분석}

\subsection{1 경제적 편익 분석}

국내의 자원회수시설은 ' 08 년말 기준으로 35 개 지역 에 총 63기가 위치하고 있다. 2009년 환경부 “생활폐기물 소각시설 설치·운영 지침”에서는 소각시설 규모별 설치단 가를 제시하고 있으나[8], 자원화시설에 이를 일률적으로 적용하기는 어렵다. 따라서 본 연구에서는 폐기물량에 따 른 자원회수시설의 설치비를 산정하기 위하여, 2000년 이후에 가동된 전국 17 개소 자원회수시설 시설용량과 설 치비 자료를 활용하여 설치비 산정을 위한 관계식을 검 토하였다. 자원회수시설의 경우에도, 폐기물 투입물 톤당 운영비의 단가는 시설 규모가 클수록 처리운영비 단가가 감소하는 추세를 나타내고 있다. 설치비 산정의 경우와 마찬가지로, 2000년 이후에 가동이 개시된 전국 17 개소 자원회수시설 시설용량과 연간 처리량, 유지관리비 자료
를 검토하였다. 이를 통해 각 시설별 처리운영비 단가를 산정하였으며, 시설 용량과 비교하여 규모별 운영비 단가 의 관계식을 Fig. 8과 9에 제시하였다.

상기의 시설 산정기준을 이용하여 설치비 및 운영비를 산정하였다. 시설비 및 운영비는 매립에 의한 폐기물 처 리비용과 비교·분석하기 위하여 20년을 내구연한으로 하 여 산정하였다. 시설용량 산정에 있어 월별 배출량의 변 동계수를 1.2 로 고려하였으며, 시설의 가동일수는 연간 330 일을 고려하여 산정하였다. 산정된 시설용량 규모에 따라 상기에서 산정된 시설규모별 설치비 및 운영비의 관계식을 적용하여 향후 20 년간의 소요 비용을 산정하였 으며, 각 시·군별 생활폐기물의 불연성 비율에 따라 매립 량을 산정하고 그에 따른 매립비용을 산정하여 총 처리 비용을 산정하였다. 또한, 최근에는 폐기물 관련시설에 대한 혐오감 및 사회적 갈등을 방지하는 방안의 하나로 자원회수시설에 주민편익시설을 설치하여 지역주민들에 대한 편의를 제공한다. 따라서 시설 설치비의 $10 \%$ 를 주 민편익시설 설치비로 산정하였다[8].

$$
\begin{aligned}
& \text {-시설용량 }(\text { 톤 } / \text { 일 })=\text { 일배출량 }(\text { 톤 } / \text { 일 }) \times 1.2 \times \frac{365}{330} \\
& \text {-주민편익시설 설치비 }=\text { 시설 설치비 } \times 10 \%
\end{aligned}
$$


자원회수시설의 운영으로부터 부가적으로 얻을 수 있 는 경제적 편익은 스팀에 의한 열 공급 또는 전력생산 등 이다. 시설의 운영으로 소각여열이 발생하고 이를 회수하 여 자체 이용하거나 또는 주변지역의 농공 및 산업단지 또는 주거지역에 스팀을 공급하여 판매수익을 얻을 수 있다. 또는, 발전시설을 가동하여 전력을 판매함으로서 수익을 창출할 수 있다.

일반적으로, 소각에 의해 발생되는 증기발생량을 활용 하여 전력을 생산 및 판매하는 것보다는 인근지역의 산 업단지나 주거지역에 스팀을 공급하여 수익을 창출하는 것이 경제성이 훨씬 높다[7]. 그러나 이를 위해서는 인근 지역에 발산된 스팀이 충분히 활용될 수 있는 수요처가 위치하고 있는 곳에 자원회수시설이 입지해야 하나 NIMBY 현상 등으로 인해 실제적으로 어려움이 많으며, 강원도 여건상 적합한 수요처를 확보하기 어려운 실정이 다. 따라서 본 연구에서는 인근지역에 대한 스팀의 판매
수익은 경제적 편익 산정에 고려하지 않았다. 발전시설을 가동하여 전력을 생산하는 경우, 일반적으로 시설용량 100 톤/일 미만의 시설에서는 경제성이 없는 것으로 나타 났다. 따라서 시설용량 100 톤/일 이상의 시설에서만 발전 시설을 가동하는 것으로 고려하여 100 톤/일을 초과하는 용량분의 전력생산에 의해서 경제적 편익이 창출되는 것 으로 가정하였다. 또한, 소각에 따른 증기발생량 중 소각 시설에서 자체적으로 평균 $21 \%$ 가 이용되므로, 이를 제외 한 나머지 부분에 대한 전력생산량을 산정하여 경제적 편익을 분석하였다.

소각시설의 증기발생량 및 전력생산량, 판매수익 등은 2008년 환경부 “폐기물 에너지화사업의 경제성 분석 연 구”의 자료를 이용하였고, 전력판매단가는 '07년 평균 계 통한계가격(SMP) 83.74원/kWh에 발전차액 지원수준인 5 원/kWh를 추가 적용하여 88.74원/kWh를 적용하였다[7].

[표 5] 시·군별 단독 및 자원회수시설에 의한 생활폐기물 처리비용 산정

[Table 5] Cost analysis results for municipal waste treatment by individual and multi regional resource recovery facility by incineration

\begin{tabular}{|c|c|c|c|c|c|c|c|c|}
\hline 구 분 & $\begin{array}{l}\text { 시설용량 } \\
\text { (톤/일) }\end{array}$ & $\begin{array}{c}\text { 처리비용 } \\
\text { (시설+운영+매립) } \\
\text { (백만원) }\end{array}$ & $\begin{array}{l}\text { 전력생산 } \\
\text { 순 수익 } \\
\text { (백만원) }\end{array}$ & $\begin{array}{c}\text { 최종 } \\
\text { 소요비용 } \\
\text { (백만원) }\end{array}$ & \multicolumn{2}{|c|}{$\begin{array}{c}\text { 톤당 처리비용 } \\
\text { (원/톤) }\end{array}$} & \multicolumn{2}{|c|}{$\begin{array}{c}\text { 지방비 소요액 } \\
\text { (백만원) }\end{array}$} \\
\hline 계 & 1,774 & $2,045,738$ & 36,226 & $2,009,512$ & \multicolumn{2}{|c|}{155,162} & \multicolumn{2}{|r|}{$1,929,677$} \\
\hline 춘천시 & 250 & 238,608 & 9,181 & 229,427 & \multicolumn{2}{|c|}{166,641} & & 218,163 \\
\hline 원주시 & 304 & 261,882 & 12,456 & 249,426 & \multicolumn{2}{|c|}{149,205} & & 235,748 \\
\hline 강릉시 & 217 & 206,508 & 7,122 & 199,386 & \multicolumn{2}{|c|}{167,360} & & 189,639 \\
\hline 동해시 & 98 & 126,159 & - & 126,159 & \multicolumn{2}{|c|}{233,541} & & 121,739 \\
\hline 태백시 & 59 & 83,437 & - & 83,437 & \multicolumn{2}{|c|}{257,427} & & 80,785 \\
\hline 속초시 & 119 & 144,753 & 1,156 & 143,597 & \multicolumn{2}{|c|}{219,540} & & 138,245 \\
\hline 삼척시 & 98 & 132,855 & - & 132,855 & \multicolumn{2}{|c|}{247,610} & & 128,465 \\
\hline 홍천군 & 56 & 78,337 & - & 78,337 & \multicolumn{2}{|c|}{254,896} & & 75,823 \\
\hline 횡성군 & 39 & 67,384 & - & 67,384 & \multicolumn{2}{|c|}{311,846} & & 65,616 \\
\hline 영월군 & 34 & 60,670 & - & 60,670 & \multicolumn{2}{|c|}{324,649} & & 59,141 \\
\hline 평창군 & 203 & 191,167 & 6,311 & 184,856 & \multicolumn{2}{|c|}{165,292} & & 175,706 \\
\hline 정선군 & 33 & 53,384 & - & 53,384 & \multicolumn{2}{|c|}{294,875} & & 51,903 \\
\hline 철원군 & 29 & 49,635 & - & 49,635 & \multicolumn{2}{|c|}{314,785} & & 48,345 \\
\hline 화천군 & 33 & 57,066 & - & 57,066 & \multicolumn{2}{|c|}{317,777} & & 55,597 \\
\hline 양구군 & 31 & 55,202 & - & 55,202 & \multicolumn{2}{|c|}{325,946} & & 53,817 \\
\hline 인제군 & 82 & 107,644 & - & 107,644 & \multicolumn{2}{|c|}{238,991} & & 103,959 \\
\hline 고성군 & 27 & 44,344 & - & 44,344 & \multicolumn{2}{|c|}{296,844} & & 43,122 \\
\hline 양양군 & 63 & 86,701 & - & 86,701 & \multicolumn{2}{|c|}{250,039} & & 83,864 \\
\hline 광역처리 & $\begin{array}{l}\text { 시설용량 } \\
\text { (톤/일) }\end{array}$ & $\begin{array}{c}\text { 처리비용 } \\
\text { (시설+운영+매립) } \\
\text { (백만원) }\end{array}$ & $\begin{array}{l}\text { 전력생산 } \\
\text { 순 수익 } \\
\text { (백만원) }\end{array}$ & $\begin{array}{l}\text { 운송비 } \\
\text { (백만원) }\end{array}$ & $\begin{array}{c}\text { 최종 } \\
\text { 소요비용 } \\
\text { (백만원) }\end{array}$ & & $\begin{array}{l}\text { 당 처리비용 } \\
\text { (원/톤) }\end{array}$ & $\begin{array}{c}\text { 지방비 } \\
\text { 소요액 } \\
\text { (백만원) }\end{array}$ \\
\hline 계 & 1,774 & $1,492,657$ & 77,817 & 74,536 & $1,489,376$ & & 152,637 & $\begin{array}{r}1,356,31 \\
7 \\
\end{array}$ \\
\hline A권역 & 342 & $\begin{array}{l}302,408 \\
\end{array}$ & $\begin{array}{l}14,807 \\
\end{array}$ & 111,249 & 298,849 & & 158,675 & 273,167 \\
\hline B권역 & 291 & 265,621 & 11,667 & 13,506 & 267,460 & & 167,097 & 245,633 \\
\hline C권역 & 399 & 316,880 & 18,268 & 9,488 & 308,100 & & 140,357 & 278,167 \\
\hline $\mathrm{D}$ 권역 & 329 & 273,706 & 13,996 & 16,733 & 276,443 & & 152,697 & 251,756 \\
\hline E권역 & 412 & 334,042 & 19,079 & 23,560 & 338,524 & & 149,254 & 307,595 \\
\hline
\end{tabular}

"운송비는 생활폐기물의 광역시설로의 운송비를 나타냄 


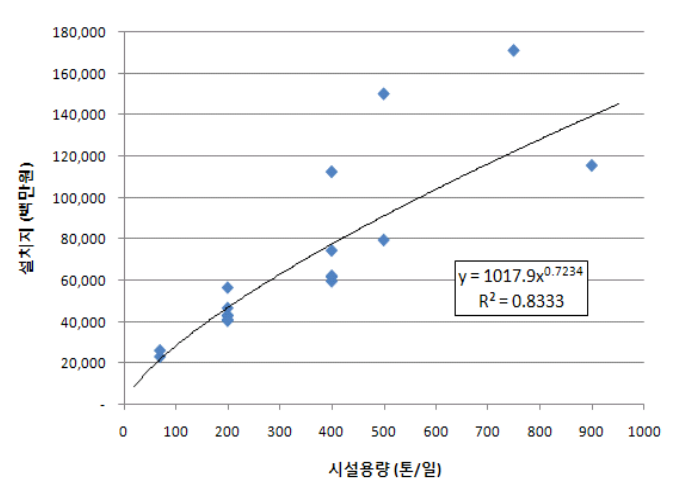

[그림 8] 자원회수시설 용량과 설치비의 상관관계

[Fig. 8] Relationship between capacity and installation cost of resource recovery facility by incineration

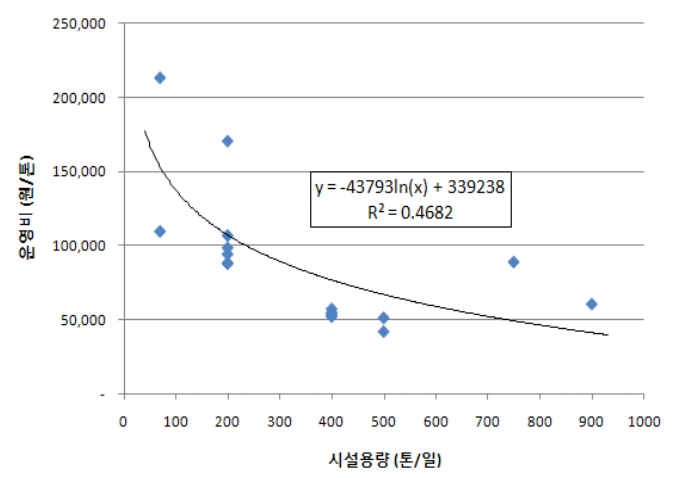

[그림 9] 자원회수시설의 규모별 운영비 단가

[Fig. 9] Relationship between capacity and installation cost of resource recovery facility by incineration

전력생산에 의한 순수익을 고려한 최종 소요비용과 톤 당 처리비용을 산정하고, 국비 지원기준(국비 $30 \%$ 지원) 을 고려하여 지방비 소요액을 산정하였다. 자원회수시설 의 경우에는, 매립이나 RDF 시설에 비해 더 많은 비용이 소요되는 것으로 나타났다. 강원도 각 시군이 모두 단독 으로 자원회수시설을 설치할 경우 매립비용보다 20년간 약 9,642억원이 더 소요되어 약 2 배의 비용이 소요되며, $\mathrm{RDF}$ 시설(단독)을 설치하여 운영하는 비용보다도 약 6,800 억원이 더 소요되는 것으로 분석되었다. 또한, 폐기 물 톤당 처리단가에서도 매립 86,692원/톤, $\mathrm{RDF}$ (단독) 91,535 원/톤에 비해 매우 높은 155,162 원/톤인 것으로 나 타났다.

이와 같이 환경적 편익을 고려하지 않고 시설비와 운 영비를 고려할 때, 시군별로 단독 자원회수시설을 설치 및 운영하는 것은 경제적인 측면에서 매우 바람직하지 못한 결과를 나타내었다. 특히, 일부 시군을 제외한 지자
체가 전력생산에 대한 경제성을 충족시키지 못하는 소규 모 용량이므로 경제성을 더욱 악화시키는 요인이 되고 있다. 따라서, 시군의 단독 자원회수시설의 설치는 매립 지의 사용연한을 증대시켜 사회적 갈등을 최소화하는 데 있어서는 효율적인 방안이 될 수 있으나, 경제적인 손실 이 매우 크다는 것을 나타내고 있다.

광역화할 경우, 각 시군별로 단독 자원회수시설을 설 치할 경우와 동일한 산정기준을 이용하여, 설치비 및 20 년간의 운영비를 산정하였다. 시설용량, 가연성 및 불연 성폐기물의 산정방식, 전력생산에 의한 순수익 또한 동일 한 기준을 활용하여 분석하였다. 운송비 수거된 자원화대 상 생활폐기물이 광역 시설이 입지된 지역까지 운송되는 비용을 산정하였다. 광역화시설의 경우 시설설치비에 대 해 국비 $50 \%$ 가 지원되는 것을 기준으로 지방비 소요액 을 산정하였다. 광역화의 경우, 시설설치 및 운영에 소요 되는 지방비는 향후 20 년 동안 약 13,563 억원이 소요되 는 것으로 나타났다. 이는 시군별로 단독시설을 설치하 는 것에 비해 약 6,800 억원의 지방비를 절감하는 효과가 있으나, 매립방식에 비해서도 약 3,908 억원의 비용이 증 가하는 것으로 나타났으며, $\mathrm{RDF}$ 광역시설에 비해서는 약 5,824 억원의 비용이 증가하는 것으로 분석되어, 경제 성 측면에서는 효율성이 저하되는 것으로 나타났다.

\subsection{2 환경적 편익 분석}

자원회수시설은 폐기물을 소각하여 발생되는 열을 활 용하여 스팀 또는 전력을 생산함으로써 원유사용을 대체 할 수 있는 환경적 편익을 지닌다. 따라서, 자원회수시설 의 설치 및 운영으로 인해 기대되는 매립지의 사용연한 증대, 원유대체효과(T.O.E), 온실가스감축량, CERs 등에 대한 환경적 편익을 분석하였다.

분석시, 매립지의 사용연한은 가연성폐기물의 비율을 이용하여 산정하였으며, 전력생산량에 의한 원유대체효 과를 분석하였다. 또한 소각시 발생되는 에너지 중 소각 시설 자체에서 이용되는 에너지도 원유대체효과에 함께 분석되었다. 전력생산량을 TOE로 환산하기 위한 $1 \mathrm{kWh}$ 는 $860 \mathrm{kal}$ 로 환산하여 적용하였다[9].

시군별 단독으로 자원회수시설이 설치되는 경우에는 소각시설 자체에서 이용되는 에너지량을 평가하였으며, 발전시설을 통한 전력생산량을 산정해 원유대체효과를 평가하였다. 자원회수시설이 운영될 경우, 매립지의 사용 연한은 현재 9년에 비해 약 4.6배 증가할 것으로 산정되 어 강원도는 평균적으로 약 41 년간의 사용연한을 확보할 수 있을 것으로 분석되었다. 또한, 향후 20년간 약 93 만 $\mathrm{TOE}$ 의 원유대체효과를 기대할 수 있으며, 이에 따른 온 실가스 감축량은 약 360 만톤으로서 약 540 억원의 CERs 
[표 6] 시·군별 단독 및 광역 자원회수시설 운영에 따른 환경적 기대효과

[Table 6] Environmental effect by the operation of resource recovery facility by incineration

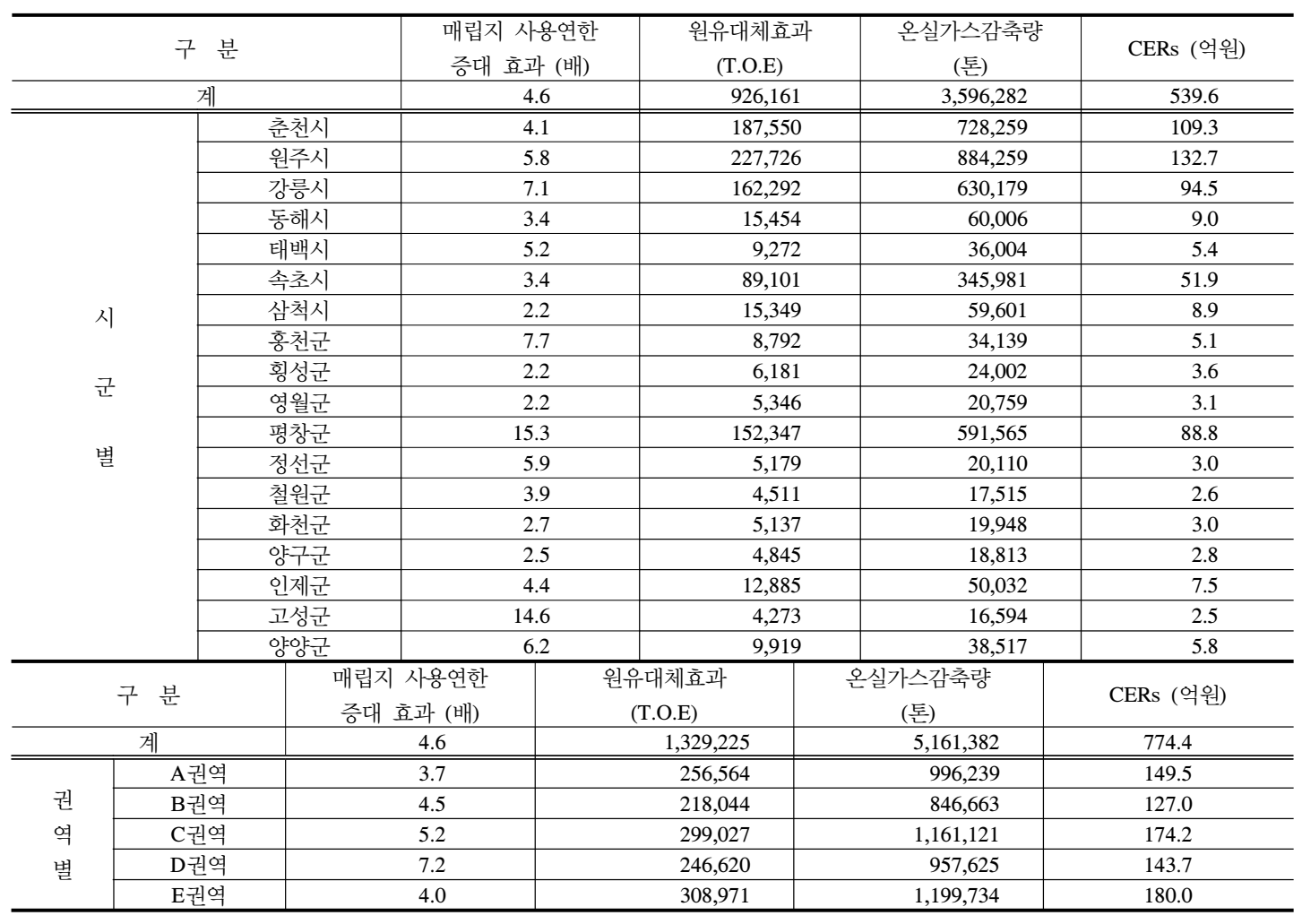

에 해당하는 것으로 $\mathrm{RDF}$ 시설에 비해 약 $1 / 5$ 수준인 것 으로 평가되었다. 광역 자원회수시설을 운영할 경우, 원 유대체효과는 약 133만 TOE를 기대할 수 있으며, 온실가 스 감축량은 약 516만톤으로서 이는 약 774 억원의 CERs 에 해당하는 것으로 나타났다. 이는 RDF 시설의 2,564억 원에 비해 약 1,790 억원 정도가 낮은 수준인 것으로 평가 되었다.

\subsection{3 단독 및 광역화 시설 운영비용 분석}

가연성폐기물의 에너지화에 대해서는 현재 많은 논란 이 있는 것이 사실이다. 기존의 매립방식에 대한 처리비 는 과다 산정되었으며, 자원화시설에 의한 처리 및 제조 비용은 지나치게 감소되고, 에너지회수율, 원유대체효과 및 온실가스저감효과 등은 지나치게 부풀려 졌다는 등 폐자원 에너지화는 환경적, 경제적으로 바람직하지 못하 다는 다양한 반론이 있다. 이러한 부분에 대해서는 중앙 정부, 지자체, 연구기관, 시민단체 등의 협력하여 정확하 고 합리적인 평가가 계속 이루어질 필요가 있을 것이다. 본 연구에서는 강원도에서 배출되는 생활폐기물을 대상
으로 하여 자원화 가능한 대상 폐기물량을 검토하고, 이 에 대한 자원화시설의 설치 및 운영 시 매립비용과의 비 교분석을 통해 그 타당성을 검토하고자 하였다.

자원화시설로는 고형연료화(RDF) 시설과 자원회수시 설(소각)에 대한 검토를 수행하였다. 또한, 강원도 각 시 군별로 자원화시설을 단독으로 설치하였을 경우와 자원 화가능 대상폐기물의 배출량에 따라 설정된 광역권(안) 에 따라 광역화하였을 경우에 대한 편익을 비교·분석하였 다. 이를 위해, 중앙정부 및 관련 연구기관에서 제시된 시 설별 비용단가 및 에너지화 관련 변수(발열량, 용량, 증기 및 전력생산량 등)를 사용하여 자원화시설에 대한 설치 비 및 운영비를 산정하였다. 또한, 강원도의 현실적인 관 리 여건을 반영하고자 매립지 설치 및 운영비용, 생활폐 기물 관리비용, $\mathrm{RDF}$ 시설비 및 운영자료 등의 자료 분석 을 통해 설치비 및 운영비용 산정에 최대한 반영하였다. 상기의 자료들을 활용하여, 생활폐기물 배출량에 대한 향 후 20 년간의 매립비용, 고형연료화(RDF) 시설 및 자원회 수시설(소각)을 강원도 내 각 시군별로 단독 설치하여 운 영할 경우와 광역화하여 운영할 경우에 대한 비용을 분 
석하였다.

표 7에 제시한 바와 같이, $\mathrm{RDF}$ 시설을 광역화하는 경 우에는 매립방식에 비해 상당한 비용을 감소시킬 수 있 는 것으로 나타났다. 이외의 경우에는 매립방식보다는 비 용이 더 소요되는 것으로 나타났다. 비용이 더 소요되는 측면이 있으나, 가용자원의 고갈 및 지구온난화, 매립으 로 인한 환경 위해성 및 이로 인해 유발되는 지역주민간 의 갈등으로 인한 사회적비용 소모 등을 고려할 때 버려 지는 생활폐기물의 자원화는 무시될 수 없는 중요한 부 분이다. 생활폐기물을 자원화에 있어, 규모상의 경제적 타당성 및 광역화에 따른 국비 지원율의 제고 등으로 단 독 시설보다는 광역화를 통한 시설 설치 및 운영이 경제 적인 측면에서 상당히 효율적이라는 것을 분명히 나타내 고 있다.

[표 7] 생활폐기물 처리방식별 지방비 소요액

[Table 7] Investment cost from local governments for each facility type

\begin{tabular}{c|c|c|c|c|c}
\hline \multirow{2}{*}{ 구 분 } & \multirow{2}{*}{ 매립 } & \multicolumn{2}{|c|}{$\mathrm{RDF}$ 비석(반원) } \\
\cline { 3 - 6 } & & 단독 & 광원) & \multicolumn{2}{c}{ 자원회수시설(백만원) } \\
\hline 계 & 965,486 & $1,249,59$ & 773,89 & $1,929,67$ & $1,356,31$ \\
\hline \hline $\mathrm{A}$ 권역 & 189,711 & 241,917 & 159,73 & 375,922 & 273,167 \\
\hline B권역 & 165,060 & 248,809 & 149,73 & 369,190 & 245,633 \\
\hline C권역 & 210,503 & 231,833 & 147,63 & 377,187 & 278,167 \\
\hline D권역 & 183,347 & 238,735 & 145,08 & 367,535 & 251,756 \\
\hline E권역 & 216,866 & 288,234 & 171,78 & 439,843 & 307,595 \\
\hline
\end{tabular}

앞에서 언급한 바와 같이, 자원화시설의 환경적, 경제 적 편익에 대해서는 아직 많은 논란이 있어 매립방식과 의 비교에는 향후 세부적인 연구가 필요할 것으로 판단 되나, 동일한 기준으로 분석된 단독시설과 광역시설은 그 편익을 분명히 나타내고 있다. 또한, 현재의 환경부 산정 기준을 이용하여 평가한 원유대체 효과 및 이에 따른 $\mathrm{CERs}$ (온실가스 저감인증)는 향후 $\mathrm{CDM}$ 사업이 활성화될 경우 추가적인 경제적 부가가치를 기대할 수 있다는 것 을 나타낸다. 이러한 경우, 폐기물 자원화시설은 에너지 회수 측면 이외에 환경 보호 및 경제논리 측면에서도 그 중요성이 더욱 부각될 것이다. 표 8과 9에는 생활폐기물 처리방식별 $\mathrm{CREs}$ 와 $\mathrm{CREs}$ 의 편익을 고려한 비용 소요액 에 대하여 제시하였다.
[표 8] 생활폐기물 처리방식별 CREs

[Table 8] CERs for each facility type

\begin{tabular}{c|c|c|c}
\hline \multirow{2}{*}{ 구 분 } & \multirow{2}{*}{$\begin{array}{c}\text { RDF 시설 } \\
\text { (백만원) }\end{array}$} & \multicolumn{2}{|c}{ 자원회수시설(백만원) } \\
\cline { 3 - 4 } & 256,467 & 53,956 & 77,438 \\
\hline 계 & 46,078 & 11,771 & 14,947 \\
\hline \hline A권역 & 41,684 & 6,768 & 12,703 \\
\hline B권역 & 59,404 & 14,139 & 17,421 \\
\hline C권역 & 52,275 & 10,029 & 14,368 \\
\hline D권역 & 57,027 & 11,249 & 18,000 \\
\hline E권역 & & &
\end{tabular}

[표 9] CREs의 편익을 고려한 비용 소요액

[Table 9] Investment cost considering the benefits of CERs

\begin{tabular}{c|c|c|c|c|c}
\hline \multirow{2}{*}{ 구 분 } & \multirow{2}{*}{ 매립 } & \multicolumn{2}{|c|}{$\mathrm{RDF}$ 시설(백만원) } & \multicolumn{2}{c}{ 자원회수시설(백만원) } \\
\cline { 3 - 6 } & & 단독 & 광역 & 단독 & 광역 \\
\hline 계 & 965,486 & 993,061 & 517,426 & $1,875,720$ & $1,278,879$ \\
\hline \hline A권역 & 189,711 & 195,840 & 113,635 & 364,151 & 258,220 \\
\hline B권역 & 165,060 & 207,126 & 108,040 & 362,422 & 232,930 \\
\hline C권역 & 210,503 & 172,430 & 88,219 & 363,047 & 260,746 \\
\hline D권역 & 183,347 & 186,459 & 92,777 & 357,507 & 237,388 \\
\hline E권역 & 216,866 & 231,206 & 114,755 & 428,594 & 289,595 \\
\hline
\end{tabular}

\section{4. 결론}

본 연구는 강원도내 생활폐기물을 대상으로 자원화시 설의 설치 및 운영 시 매립비용과의 비교분석을 통해 그 타당성을 검토하고자 하였다.

고형연료화 시설은 단독시설을 설치할 경우 매립비용 보다 약 2,840 억원이 더 소요되는 것으로 분석되었다. 광 역화는 단독시설에 비해약 4,750 억원 이상의 지방비가 절감되며, 매립방식에 비해서 약 1,916 억원의 비용이 절 감되어 강원도 전체에서 매년 약 95 억원의 경제적 편익 이 있는 것으로 분석되었다.

고형연료화 시설을 20 년간 운영할 경우 환경적 기대 효과를 분석한 결과, 매립지 사용연한은 현재 9년에 비해 약 3.0 배 증가할 것으로 산정되었다. 이는 향후 20 년간 약 440만 TOE의 원유대체효과를 기대할 수 있으며, 이에 따른 온실가스 감축량은 약 1,709 만톤에 달하는 것으로 분석되었다. 또한 약 2,565 억원의 CERs에 해당하는 것으 로 향후 $\mathrm{CDM}$ 사업이 활성화될 경우 추가적인 경제적 부 가가치도 기대할 수 있을 것으로 판단된다. 이러한 CERs 
에 의한 경제적 부가가치를 포함하여 고려하면, 단독시설 의 경우에도 매립에 의한 방법보다 향후 20 년간 약 276 억원의 비용이 더 소요되는 것으로 나타났으며, 광역화 시설의 경우에는 약 4,480 억원의 편익을 기대할 수 있을 것으로 분석되었다.

자원회수시설의 편익 분석결과, 단독으로 자원회수시 설을 설치할 경우 매립비용보다 20년간 약 9,642억원이 더 소요되었으며, 이는 단독 설치하여 운영하는 비용보다 도 약 6,800 억원이 더 소요되는 것으로 분석되었다. 또한, 폐기물 톤당 처리단가에서도 매립 86,692원/톤, $\mathrm{RDF}$ (단 독) 91,535 원/톤에 비해 매우 높은 155,162 원/톤인 것으로 나타났다. 광역화의 경우, 시설설치 및 운영에 소요되는 지방비는 향후 20 년 동안 약 13,563 억원이 소요되는 것 으로 나타났다. 이는 단독시설을 설치하는 것에 비해 약 6,800 억원의 지방비를 절감하는 효과가 있으나, 매립방식 에 비해서도 약 3,908 억원의 비용이 증가하는 것으로 나 타났으며, 고형연료화 광역시설에 비해서는 약 5,824억원 의 비용이 증가하는 것으로 분석되어, 경제성 측면에서는 효율성이 저하되는 것으로 나타났다.

자원회수시설에 대한 환경적 편익을 분석한 결과, 단 독으로 운영될 경우, 매립지의 사용연한은 현재 9년에 비 해 약 4.6배 증가할 것으로 산정되어 강원도는 평균적으 로 약 41 년간의 사용연한을 확보할 수 있을 것으로 분석 되었다. 또한, 향후 20 년간 약 93 만 $\mathrm{TOE}$ 의 원유대체효과 를 기대할 수 있으며, 이에 따른 온실가스 감축량은 약 360 만톤 으로서 약 540 억원의 CERs에 해당하는 것으로 $\mathrm{RDF}$ 시설에 비해 약 $1 / 5$ 수준인 것으로 평가되었다. 광 역 자원회수시설을 운영할 경우, 원유대체효과는 약 133 만 TOE를 기대할 수 있으며, 온실가스 감축량은 약 516 만톤으로서 이는 약 774억원의 CERs에 해당하는 것으로 나타났다. 이는 RDF 시설의 2,564억원에 비해 약 1,790 억원 정도가 낮은 수준인 것으로 평가되었다.

\section{References}

[1] Ministry of Environment (2007), Revision of Second Master Plan for National Waste Management (2002 2011)

[2] Ministry of Environment, Master Plan for Climate Change, 2008.

[3] Data from Dept. of Environmental Policy, Gangwon Province, 2010.

[4] Homepage of Gangwon Statistical Information, http:// stat.gwd.go.kr/
[5] Ministry of Environment, Notification No. 2008-150 of the Ministry of Environment, 「Disposal Unit Cost for Each Waste Type for Calculation of Disposal Deposit for the Abandoned Waste $\lrcorner, 2008$.

[6] Gangwon Province, A Study on New - Renewable Energy using the Combustible Waste from Military Camp, 2010.

[7] Ministry of Environment, A Study on the Econo- mic Feasibility for Renewable Energy Business using Waste, 2008.

[8] Ministry of Environment, Guide on the Installation and Operation of Incineration Facility for Municipal Waste, 2009.

[9] Ministry of Environment, Master Plan for Rene- wable Energy Business using Waste, 2008.

이 해 승(Hae-Seung Lee)

[정회원]

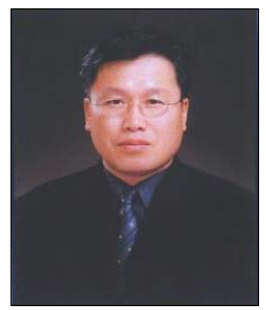

- 1989년 8월 1991년 11월 : (주)유신코퍼레이션, 환경부

- 1994년 3월 1997년 3월 : Hokkaiod University 환경위생과 (환경공학 박사)

- 1999년 2월 현재 : 강원도립 대학 소방환경방재과 교수

<관심분야>

폐기물처리, 매립지 관리

\section{한 영 한(Han-Young Han)}

[정회원]

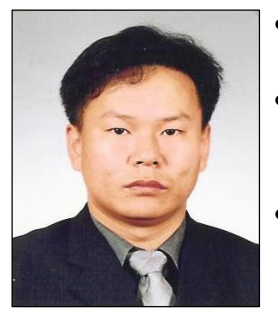

- 1996년 3월 2001년 2월 : 강 원대학교 대학원(환경공학 박사)

- 2003년 7월 2006년 6월 : 미 국 UCLA 대학교 토목환경공학 과(박사후 연구원)

- 2008년 4월 현재 : 강원발전 연구원 부연구위원

<관심분야>

수환경 및 유역관리, 폐기물관리 및 자원화 